\title{
Strategi aktivisme digital di Indonesia: aksesibilitas, visibilitas, popularitas dan ekosistem aktivisme
}

\author{
Detta Rahmawan', Jimi Narotama Mahameruaji ${ }^{2}$, Preciosa Alnashava Janitra ${ }^{3}$ \\ 1,2,3 Universitas Padjadjaran, Bandung, Indonesia
}

\begin{abstract}
ABSTRAK
Setidaknya dalam satu dekade terakhir, mayoritas masyarakat Indonesia sangat antusias mengadopsi beragam platform digital seperti media sosial dan aplikasi pesan instan. Pesatnya penetrasi teknologi ini juga kerap dibungkus dalam narasi techno-utopianism terutama dalam kaitannya dengan harapan akan pertumbuhan perekonomian digital di Indonesia. Meskipun demikian, pemanfaatan platform digital juga perlu dilihat pada konteks penguatan demokrasi, dan perubahan sosial di masyarakat. Dalam hal ini, aktivisme digital, atau peran teknologi digital dalam berbagai gerakan sosial di Indonesia menjadi penting untuk diamati. Penelitian ini menggunakan studi literatur untuk menganalisis secara kritis beragam studi terkait aktivisme digital serta memberikan ulasan terkait konsep aksesibilitas, visibilitas, popularitas dan ekosistem aktivisme sebagai mekanisme yang mendasari praktik aktivisme digital Hasil penelitian menunjukkan bahwa konsep aksesibilitas memaparkan faktor ketersediaan infrastruktur digital serta kesiapan masyarakat dalam menerima praktik aktivisme. Selanjutnya, ide terkait visibilitas dan popularitas memperlihatkan bahwa praktik aktivisme digital selalu berkaitan dengan algoritme dan metrics yang mendasari bagaimana media digital bekerja, sehingga, pelaku aktivisme digital perlu melakukan adaptasi agar aktivisme dapat menjadi "terlihat" (visible) dan "populer" pada khalayak yang tepat tanpa menghilangkan esensi dan substansi dari aktivisme tersebut. Sangat penting untuk melihat ekosistem aktivisme secara komprehensif dan holistis, dengan tidak hanya memperhatikan faktor teknologi, namun juga faktor kondisi sosial dan budaya serta konteks historis dari aktivisme dan berbagai gerakan sosial yang muncul, berkembang dan menyebar di masyarakat.
\end{abstract}

Kata-kata kunci: aktivisme digital; gerakan sosial; media digital; demokrasi; Indonesia

\section{Digital activism strategies in Indonesia: accessibility, visibility, popularity and the ecosystem of activism}

\begin{abstract}
At least in the last decade, most people in Indonesia have been very enthusiastic about adopting various digital platforms such as social media and instant messaging applications. Penetration of these technologies is also often wrapped in a techno-utopian narrative, especially related to the expectations of digital economic growth in Indonesia. However, the use of digital platforms also needs to be seen in terms of how it has potentials in strengthening democracy, one of which is related to digital activism, or the role of digital technology in various social movements in Indonesia. This research aims to study digital activism and proposes the concepts of accessibility, visibility, popularity and the activism ecosystem as the main mechanism underlying digital activism practices. The research was conducted using Literature review method. The results show that the concept of accessibility explains the availability of digital infrastructure and people's readiness to exposed by the practice of activism. Furthermore, the concepts of visibility and popularity show that the practice of digital activism is always related to the algorithms and metrics that underlie how digital media works. Thus, the actors related to digital activism need to ensure that their activism practices can becomes "visible" and "popular" for the right audience without losing its substance. Finally, it is very important to look at the activism ecosystem in a comprehensive and holistic manner, and not only consider technological factors, but also socio-cultural conditions and the historical context of activism and various social movements that emerge, develop and spread in the society.
\end{abstract}

Keywords : digital activism; social movements; digital media; democracy; Indonesia

Korespondensi: Detta Rahmawan, S.I.Kom., M.A. Universitas Padjadjaran. Jalan Raya Bandung-Sumedang KM.21 Jatinangor, Sumedang, Jawa Barat, 45363. Email: detta@unpad.ac.id 


\section{PENDAHULUAN}

Industri media di Indonesia selama tiga puluh tahun berada dalam cengkeraman Soeharto dan kroninya untuk menjadi alat propaganda dan melanggengkan kekuasaan. Pengendalian terhadap media sebagai arus informasi juga dilakukan oleh Soeharto dengan pembungkaman terhadap jurnalis dan juga media yang melakukan kritik terhadap pemerintahan. Kondisi ini berubah ketika era reformasi dimulai, dengan perubahan signifikan yang terjadi dalam dunia pers atau jurnalistik, dan juga pada industri media (Nugroho, Putri, \& Laksmi, 2012; Nugroho, Siregar, \& Laksmi, 2012).

Sejarah reformasi 1998 di Indonesia memperlihatkan salah satu bukti keberhasilan aktivisme dan gerakan sosial yang diperantarai oleh teknologi digital, meskipun teknologi yang digunakan tentu belum secanggih teknologi digital yang ada saat ini. Pergerakan di era reformasi memperlihatkan bagaimana sirkulasi dan amplifikasi informasi subversif dapat beredar di luar dari jaringan distribusi media arus utama. Informasi inilah yang kemudian menjadi bahan bakar dari simpul-simpul gerakan yang pada akhirnya dapat menjelma menjadi gelombang perubahan yang besar, seperti digambarkan Lim sebagai berikut:

"Internet pada akhirnya, membantu menguatkan gerakan mahasiswa anti-
Suharto pada tahun 1998. Para mahasiswa Menggabungkan aktivisme online dan offline, menggunakan berbagai cara komunikasi yang tidak dikontrol secara terbuka oleh pemerintah telepon, faks, telepon seluler, dan khususnya e-mail para siswa dan berbagai pihak lain melakukan mobilisasi banyak orang untuk datang ke jalan-jalan dan menempati taman, plaza, dan bagian depan gedung-gedung pemerintah untuk memaksa Presiden Soeharto untuk mundur" (Lim, 2019, hal. 484).

Setelah berakhirnya orde baru, Indonesia menghadapi masa reformasi yang berimplikasi pada terjadinya beberapa perubahan krusial dalam konteks industri telekomunikasi informatika dan konvergensi media. Upaya untuk melakukan pembangunan dalam bidang infrastruktur teknologi sebenarnya telah dilakukan oleh negara melalui Kementerian Komunikasi dan Informatika (Kominfo) sejak tahun 2010. Kendati demikian, proyek tersebut menghadapi berbagai kendala seperti permasalahan birokrasi, pemetaan akses, bahkan korupsi yang terjadi di dalam Kominfo (Wahyuni, 2013). Keterjangkauan harga telepon pintar, harga paket berlangganan internet yang ditawarkan oleh operator seluler, serta meningkatnya jumlah tempat yang menyediakan layanan koneksi wi-fi di berbagai daerah di Indonesia juga turut mewarnai perkembangan pemanfaatan internet.

Di Indonesia, penetrasi teknologi digital senantiasa mendapatkan sambutan yang positif, khususnya oleh para pelaku usaha yang 
menganggap bahwa teknologi digital berpotensi menjadi katalis bagi ekonomi digital (Rajan Anandan, Sipahimalani, Saini, Aryasomayajula, \& Smittinet, 2018). Hal ini juga didukung oleh kenyataan bahwa beberapa perusahaan media sosial media global mengidentifikasi Indonesia sebagai salah satu negara yang penting untuk pemasaran produk-produk mereka. Banyaknya jumlah penduduk yang berkontribusi terhadap akselerasi dalam bidang ekonomi digital, membuat Indonesia dilihat sebagai negara potensial bagi para pebisnis teknologi digital untuk menginvestasikan modalnya (Freischlad, 2017; Rajan Anandan et al., 2018). Namun, perkembangan teknologi yang terjadi di Indonesia tidak dapat hanya dilihat dari perspektif ekonomi. Pemanfaatan teknologi di Indonesia, sebagai salah satu negara besar di Asia Tenggara, perlu ditelaah dalam kaitannya dengan tujuan sosial, yang dapat mencakup pemberdayaan masyarakat, inovasi dalam konteks edukasi, mengatasi ketimpangan ekonomi, menyelesaikan isu hak asasi manusia, hingga gerakan-gerakan sosial lain secara luas yang membantu mewujudkan keadilan sosial, kemakmuran serta iklim demokrasi yang sehat. Hal-hal tersebutlah yang menjadikan aktivisme digital menjadi semakin relevan dan penting untuk dikaji secara kontinu.

Penelitian ini bertujuan untuk menelusuri berbagai literatur dan kajian pustaka yang mampu memberi penelaahan terkait konsep aktivisme digital, serta bagaimana praktik ini dilakukan di Indonesia dengan berbagai peluang, hambatan dan tantangan yang ada. Analisis hasil penelitian ini akan dibagi menjadi beberapa bagian sebagai berikut: Bagian pertama berisi ulasan terkait konsep historis dan perdebatan kunci terkait aktivisme digital secara global. Setelah itu, bagian selanjutnya akan memaparkan secara konseptual beragam praktik aktivisme digital dan gerakan sosial di Indonesia. Selanjutnya, secara berturut-turut penelitian ini mengeksplorasi dan menawarkan konsep aksesibilitas, visibilitas, popularitas, dan ekosistem aktivisme di Indonesia sebagai mekanisme yang relevan untuk dianalisis lebih lanjut dalam wacana aktivisme digital di Indonesia.

\section{METODE PENELITIAN}

Metode yang digunakan dalam penelitian ini adalah studi literatur tentang konsep, teori, hingga studi kasus terkait dengan fenomena aktivisme digital, yang diulas dalam berbagai sumber dan bersifat multidisipliner. Studi literatur mendalam terkait sebuah konsep telah dilakukan oleh beberapa penulis dalam jurnal ini yaitu pada artikel yang membahas Model pemrosesan informasi Gregory Bateson dalam pendekatan sibernetis (Priyadharma, 2019) dan pada artikel lain yang berisi ulasan tentang 
Chinese Harmony Communication Theory

(Mirawati \& Karimah, 2018).

Untuk memulai ulasan terkait aktivisme digital, penelitian ini akan membahas salah satu publikasi utama terkait aktivisme digital yang paling banyak dikutip yaitu Digital Activism Decoded: the New Mechanics of Change (Joyce, 2010a), sebelum kemudian melakukan berbagai penelusuran lain dalam literatur yang berasal dari negara-negara maju seperti Amerika dan berbagai negara di Eropa. Setelah itu, penelusuran juga dilakukan dengan melihat kasus-kasus di negara berkembang dan lebih spesifiknya lagi di Asia seperti dalam publikasi bertajuk Digital Activism in Asia Reader (Lim, 2019; Nishant, Puthiya, \& Sumandro, 2015), serta berbagai literatur yang spesifik membahas aktivisme digital di Indonesia (Lim, 2013, 2017; Postill \& Saputro, 2017; Rahmawan, 2018; Suwana, 2019). Secara khusus, penelitian ini memberikan penelaahan secara kritis tentang bagaimana praktik aktivisme digital berkaitan dengan konsep aksesibilitas, visibilitas, popularitas dan ekosistem media digital.

\section{HASIL DAN PEMBAHASAN}

Konsep aktivisme digital muncul ketika teknologi dapat dimanfaatkan untuk mendorong berbagai aktivitas masyarakat sipil terutama dalam konteks negara demokrasi. Selama beberapa tahun terakhir, berbagai pihak di seluruh dunia telah menjadi semakin sadar dan tertarik pada potensi penggunaan teknologi digital - mulai dari perangkat keras seperti ponsel dan perangkat lunak pendukung, seperti Internet, dan media sosial misalnya dalam konteks kampanye untuk perubahan sosial dan politik. Praktik-praktik ini lalu didefinisikan dan dipopulerkan sebagai "aktivisme digital".

Fenomena ini kemudian muncul juga di berbagai negara di dunia, dicermati dan diberitakan di media-media oleh para jurnalis, diulas oleh para pengamat politik, secara antusias telah dipelajari oleh para peneliti dan akademisi dari berbagai latar belakang disiplin yang berbeda. Selain itu, hal ini juga dipelajari oleh para juru kampanye profesional yang tertarik dengan dunia digital, dengan tujuan utamanya tidak hanya terkait dengan keinginan untuk memahami fenomena aktivisme, namun juga mengeksplorasi kemungkinan untuk mencari strategi dan taktik seperti apa yang kemudian dapat secara efektif mencapai tujuan dari sebuah praktik aktivisme (Joyce, 2010a).

Akan tetapi, dalam upaya untuk memahami aktivisme digital, yang terjadi kemudian adalah fenomena aktivisme sering direduksi menjadi anekdot dan studi kasus yang terbatas dan sangat spesifik, serta juga mayoritas terjadi dalam konteks gerakan politik. Contoh dari fenomena tersebut adalah, ketika membicarakan aktivisme digital, banyak sekali rujukan yang 
membahas kisah Barack Obama di Amerika Serikat, yang menggunakan situs jejaring sosial Facebook untuk memobilisasi sukarelawannya, terutama yang berusia muda. Aktivisme digital juga kerap melihat kisah inspiratif kontribusi media sosial pada eskalasi protes politik yang dapat menggulingkan penguasa otoriter, seperti pada fenomena revolusi di negara-negara Arab yang disebut dengan Arab Spring (Joyce, 2010a). Anekdot dan studi kasus ini kemudian diberitakan, dipuji, dan juga telah dikritik secara luas. Beberapa pelajaran dan praktik terkait aktivisme digital telah coba diekstraksi untuk dapat diterapkan ke kampanye lain. Namun faktanya, tentu replikasi ini tidak dapat secara langsung digunakan dalam kondisi sosial yang kompleks dan terfragmentasi (Joyce, 2010b). Hal ini dijelaskan sebagai berikut:

"Konteks aktivisme digital mengacu pada teknologi digital yang digunakan dalam kampanye dan aktivisme tertentu dan pada konteks ekonomi, sosial, dan politik [di mana] penggunaan teknologi tersebut terjadi. Infrastruktur teknologi digital kombinasi dari jaringan, kode, aplikasi, dan perangkat yang membentuk infrastruktur fisik aktivisme digital adalah titik awal tetapi bukan titik akhir. Perbedaan dalam faktor ekonomi, sosial, dan politik pada akhirnya [akan] mengubah cara aktivis menggunakan teknologi ini" (Joyce, 2010b, hal. 2).

Jika kajian terkait aktivisme digital terlalu berfokus pada anekdot dan studi kasus yang "populer" di media, pemahaman terkait aktivisme digital dikhawatirkan akan terlalu sempit dan terbatas karena penggunaan dan relevansi berbagai alat, strategi dan taktik digital akan terus berubah. Berbagai literatur telah menyerukan untuk beralih dari anekdot dan studi kasus yang hanya memperlihatkan apa yang terjadi dan terlihat secara luas di permukaan (misalnya saja dari penggambaran yang dikemas di media) kepada "landasan mekanis", “faktor kontekstual”, “nilai”, maupun "struktur sosial" yang memungkinkan aktivisme digital terjadi (Joyce, 2010a; Lim, 2019). Pemahaman terkait hal-hal ini akan secara fundamental mengungkap bagaimana teknologi digital, dalam hal ini, misalnya, dianggap dapat menciptakan ruang-ruang publik baru untuk proses komunikasi, dan interaksi yang terjadi secara demokratis dan organik, untuk memecahkan berbagai permasalahan publik, serta menyuarakan dan mengamplifikasi kepentingan publik yang riil di masyarakat (Friedland, Hove, \& Rojas, 2006; Lim, 2003).

Terminologi dan frasa "aktivisme digital" juga hingga kini masih menjadi perdebatan secara akademis. Meskipun demikian, "digital" dalam hal ini disepakati sebagai potensi kecepatan, reliabilitas, skala, dan biaya rendah yang ditawarkan teknologi digital, dan hal ini memungkinkan terjadinya perluasan jangkauan dan ruang lingkup aktivisme kontemporer. Istilah aktivisme digital kemudian dapat merujuk pada serangkaian kegiatan ataupun kampanye 
yang menggunakan teknologi dan jaringan digital secara komprehensif dan eksklusif. Komprehensif dalam hal ini mencakup semua praktik kampanye sosial dan politik yang menggunakan infrastruktur jaringan digital; eksklusif berarti tidak termasuk bentuk-bentuk praktik aktivisme lain yang menggunakan teknologi, namun tidak tersambung dalam sebuah infrastruktur jaringan digital (Joyce, 2010a).

Bagian pertama dari analisis pada penelitian ini akan mengulas tentang aktivisme digital dan partisipasi publik. Aktivisme digital dikatakan dapat berpotensi meningkatkan partisipasi publik dalam sebuah gerakan sosial, dan contoh dari praktik ini telah terjadi pada berbagai negara di dunia. Akan tetapi, apakah seluruh kegiatan yang dilakukan publik secara online dapat dilihat sebagai "partisipasi"? Perdebatan terkait hal-hal apa saja yang dapat diakui sebagai partisipasi publik telah dilakukan oleh para pengkaji aktivisme digital. Terdapat pihak yang skeptis bahwa menulis opini, berbagi berita politik, perdebatan panas dalam forum-forum online, maupun menulis dan membagikan petisi online adalah bentuk dari aktivisme. Hal ini juga dipengaruhi oleh adanya istilah-istilah peyoratif seperti click activism, slacktivism, maupun keyboard activism. Di sisi lain, terdapat argumen bahwa praktik aktivisme yang diperantarai oleh komunikasi dan interaksi secara online tetap harus menghasilkan gerakan masal, protes di jalanan, ataupun berbagai kegiatan lain yang bersifat offline (Lim, 2013). Akan tetapi, pada titik inilah akademisi seperti Paolo Gerbaudo justru mengingatkan bahwa aktivisme digital tidak boleh direduksi menjadi selalu bernuansa tekno-determinis yang sekadar dapat dievaluasi keberhasilannya lewat adanya praktik mobilisasi massa ataupun praktik lain yang "jelas" terlihat dan pada umumnya menjadi bahan pemberitaan media (Gerbaudo, 2017).

Dalam hal ini para pengkaji aktivisme digital memperlihatkan sikap skeptisnya karena selama tahun 2011 dan 2012, pemberitaan di media-media berita arus utama besar di Amerika dan Eropa kerap membangun wacana bahwa media sosial seperti Facebook dan Twitter menjadi faktor utama penyebab tumbangnya rezim-rezim otoriter pada beberapa negara Afrika dan Timur Tengah. Media juga dengan cepat mengamplifikasi istilah popular seperti "Arab Spring" dengan kacamata pemberitaan yang bernada optimistis bahwa "revolusi secara digital" telah terjadi. Tidak hanya tentang Arab Spring, gerakan-gerakan sosial setelahnya, seperti gerakan massa di Hongkong yang terkenal dengan istilah "Umbrella Movement", hingga gerakan reformasi politik di Malaysia "Bersih Movement" juga diberitakan dengan nada yang meng-glorifikasi peran media sosial 
(Lim, 2018).

Dalam konteks inilah diperlukan analisis yang lebih mengeksplorasi bagaimana konteks sosial budaya dan politik lokal juga adalah bagian penting dalam sebuah aktivisme digital yang menghasilkan mobilisasi massa. Memudarnya analisis yang berusaha untuk lebih jauh menggali konteks lokalitas ini dapat membuat penggambaran praktik aktivisme menjadi ahistoris. Padahal, aktivisme digital tentu tidak dapat lepas dari nuansa ekonomi-politik yang melingkupi praktik-praktik penggunaan teknologi serta kompleksitas jaringan lokal dan kaitannya dengan jaringan global dalam sebuah gerakan. Analisis aktivisme digital juga perlu untuk selalu mengelaborasi peran aktor, atau manusia (human agency) yang berada di balik teknologi (Treré, Jeppesen, \& Mattoni, 2017).

Dalam praktik aktivisme, teknologi digital tidak hanya dilihat sebagai sarana untuk "berbicara secara lebih cepat dan luas" namun juga untuk "mendengarkan secara lebih seksama dan mendalam" secara digital. Karpf mengeksplorasi isu ini dalam konsepnya "analytic activism", yang lebih melihat bagaimana para aktivis dapat mengubah data yang berserakan di internet menjadi sumber daya yang berharga untuk memperbaharui strategi dan taktik yang dapat dilakukan oleh sebuah organisasi (Karpf, 2018). Hal-hal yang dimungkinkan terkait dengan teknologi digital ini seperti; pengelolaan reputasi organisasi, mempermudah komunikasi dan koordinasi antar pihak dan aktor yang terlibat dalam sebuah gerakan sosial, memfasilitasi proses penggalangan dana, pendanaan kegiatan rutin, pengumpulan anggota, dan menambah variasi dalam melakukan strategi dan taktik organisasi dalam menyampaikan pesan kepada pihak luas. Berbagai hal yang telah disebutkan ini adalah variabel yang tersembunyi dan sering kali vital dalam keberhasilan maupun kegagalan proses aktivisme (Karpf, 2016). Utilitas teknologi digital juga dapat dilihat dalam konteks bagaimana organisasi dapat memiliki akses pada sejumlah besar data terkait isu-isu yang mereka peduli, dan bagaimana masyarakat luas membicarakan, mendiskusikan, hingga mungkin membantah isu tersebut.

Kajian terhadap aktivisme digital yang hanya berfokus pada aspek teknologi cenderung terbatas pada bias optimistik, yakni melihat platform media sosial sebagai teknologi yang membuka ruang-ruang publik demokratis. Faktanya, media sosial justru rentan untuk menjadi objek manipulasi terutama oleh berbagai pihak yang memiliki kepentingan untuk menyebarkan kebencian, prasangka emosi negatif. Salah satu contoh nyata dalam konteks di Indonesia yaitu algoritme media sosial ternyata turut mendukung pembentukan kelompok-kelompok yang kemudian saling 
menyerang ketimbang melakukan diskusi dalam lingkungan yang sehat (Lim, 2017). Karena itu, diperlukan analisis komprehensif terhadap aktivisme digital dengan berbagai perspektif multidisipliner agar dapat keluar dari jebakan bias techno-determinism (Lim, 2018).

Selanjutnya, akan digambarkan beberapa studi terkait aktivisme digital di Indonesia. Gambaran mengenai aktivisme digital di Indonesia dapat diamati melalui riset berjudul “@ksi Warga”. Riset yang dilakukan oleh Yanuar Nugroho setelah reformasi ini memetakan beragam penggunaan media digital oleh organisasi masyarakat sipil Indonesia. Hasil riset menunjukkan bahwa media sosial berperan penting untuk perubahan jika media ini diadopsi dan dimanfaatkan oleh organisasi masyarakat sipil dengan tepat, strategis, serta efektif (Nugroho, 2011). Referensi lain yang juga berfokus pada aktivisme digital dari Lim menggambarkan bagaimana aktivisme digital menjadi gerakan sosial yang subversif dan tumbuh secara organik di tengah masyarakat. Riset ini menunjukkan peran signifikan internet dalam menyatukan masyarakat sipil dalam identitas kolektif yang bertujuan "melawan" tekanan pemerintahan Soeharto. Selain identitas kolektif dalam reformasi, studi kasus lain terkait aktivisme digital juga ditunjukkan oleh konflik yang terjadi antara Prita Mulyasari dan Rumah Sakit Internasional Omni Hospital serta kasus
"Cicak vs Buaya" yang melibatkan aktivis antikorupsi, masyarakat, dan pihak kepolisian (Lim, 2013).

Sementara itu, kajian lain membuat kategori terkait nuansa aktivisme digital di Indonesia yang sering muncul, yaitu korban", "relawan" dan "suara". Ketiga kategori ini dapat diamati pada kasus Prita Mulyasari dalam posisinya sebagai korban Undang-Undang terkait Informasi dan Transaksi Elektronik (UU ITE), gerakan relawan kawal pemilu pada pemilihan presiden di tahun 2014, serta situs Suara Papua yang dapat dijadikan contoh pemanfaatan media digital untuk menyuarakan pandangan alternatif terkait Papua (Postill \& Saputro, 2017).

Di samping aspek politik, studi mengenai aktivisme digital di Indonesia dalam konteks komunitas online juga telah dilakukan. Salah satu studi misalnya berfokus pada komunitas "Kaskuser" di Solo, Jawa Tengah yang terlibat dalam pergerakan sosial walaupun anggota komunitas tidak menyatakan bahwa mereka adalah aktivis. Riset ini menunjukkan dinamisnya relasi online-offline dan bagaimana faktor kebudayaan masyarakat turut berperan (Seto, 2017). Pada kajian lain yang dilakukan oleh Suwana (2019) terhadap gerakan "SaveKPK", digambarkan faktor internal yang terkait dengan motivasi partisipasi anak muda dalam gerakan tersebut. Faktor internal yang dimaksud misalnya keinginan mengirimkan 
informasi yang terpercaya, mempertahankan eksistensi dan citra KPK, kepercayaan untuk berpartisipasi dalam transformasi sosial dan politik, serta orientasi terhadap sistem politik yang lebih baik (Suwana, 2019). Aktivisme digital telah menciptakan peluang baru yang mendukung partisipasi anak muda dalam perubahan sosial. Terkait hal ini, aktivisme dan partisipasi politik juga dapat dipandang sebagai ekspresi anak muda. Kegagalan mewujudkan ruang publik yang sehat dan demokratis antar anak muda berpotensi menumbuhkan kooptasi kekuatan lain terhadap ruang tersebut. Adapun kekuatan tersebut dapat berupa propaganda pemerintah yang manipulatif, gerakan konservatif yang irasional, hingga ekstremisme yang cenderung anti terhadap beragam bentuk kemajuan masyarakat yang demokratis (Rahmawan, 2018).

Aktivisme digital bukanlah sebuah fenomena tercipta dalam ruang vakum. Setiap praktik aktivisme akan menorehkan keberhasilan, kegagalan, peluang, tantangan, maupun hambatan, yang berbeda. Pada bagian selanjutnya, akan dipaparkan berbagai argumen terkait konsep-konsep krusial terkait bagaimana aktivisme digital terutama dalam konteks Indonesia, dapat tumbuh, berkembang, tersebar, dan menghasilkan gerakan yang konkret dan berkelanjutan.

Konsep pertama yang akan dibahas adalah terkait aksesibilitas pada praktik aktivisme digital. Aktivisme digital akan selalu terkait dengan infrastruktur jaringan digital. Praktik aktivisme ini membutuhkan perangkat yang saling berhubungan dan secara teknis menggunakankode-kodebinerdalam pertukaran informasi. Aktivisme digital membutuhkan jaringan untuk melakukan distribusi informasi dan membuat konektivitas antara pusat gerakan kepada simpul-simpul gerakan lain. Infrastruktur telekomunikasi membuat sejumlah warga negara dapat lebih mudah terhubung satu sama lain, saling mengirim dan menerima pesan, serta mengoordinasikan tindakan terkait sebuah gerakan politik maupun gerakan sosial. Perbedaan ketersediaan jaringan dari satu negara ke negara lain memperlihatkan bagaimana faktor infrastruktur, ekonomi, sosial, dan politik mengarah pada praktik aktivisme digital yang berbeda. Pada negara maju yang jaringannya mayoritas terbangun oleh infrastruktur kabel modern, seperti serat optik, tentu terdapat jaminan akan koneksi internet yang cepat dan membuat praktik aktivisme digital dengan berbagai bentuk dan variasi dapat dilakukan secara lebih leluasa. Masyarakat di negara ini juga memiliki potensi untuk lebih berpartisipasi dalam aktivisme digital karena aksesibilitas terhadap biaya dan kualitas koneksi internet yang tersedia untuk mereka (Joyce, 2010b). 
Di Indonesia, meskipun dalam beberapa tahun terakhir ini pembangunan infrastruktur terus dilakukan dan diharapkan menjadi salah satu jembatan yang dapat mengurangi ketimpangan dalam masyarakat Indonesia, faktanya kesenjangan akses dan ketersediaan infrastruktur digital jelas masih terjadi (Hadi, 2018)the gap of rural-urban internet access remains a great challenge. As reported in the 2016 Information and Communication Technology (ICT. Kesenjangan infrastruktur digital di Papua, Nusa Tenggara Timur dan Sulawesi Tengah masih menjadi faktor utama yang menghambat penerimaan dan pemanfaatan inovasi digital secara merata (Ariyanti, 2013). Data lain di tahun 2018 juga memperlihatkan bahwa Papua, Nusa Tenggara Timur, Sulawesi Barat, Maluku Utara, Nusa Tenggara Barat, Aceh, Lampung, dan Kalimantan Barat masih tercatat sebagai daerah dengan indeks pembangunan teknologi informasi dan komunikasi (IP-TIK) paling rendah (Badan Pusat Statistik, 2018). Dengan tingkat kesenjangan yang tinggi antara pulau Jawa dan pulau-pulau lain di Indonesia, bukanlah sebuah kebetulan apabila apa yang kemudian tercatat sebagai praktik aktivisme digital di Indonesia mayoritas berada di pula Jawa.

Hal ini berbanding lurus dengan fakta bahwa aksesibilitas masyarakat kepada berbagai bentuk inovasi digital masih sangat terpusat di pulau Jawa. Aksesibilitas terkait infrastruktur juga membuat masyarakat Indonesia memiliki pola penggunaan perangkat teknologi digital yang cenderung berbasiskan teknologi broadband dan bersifat mobile. Fakta bahwa mayoritas pengguna internet di Indonesia melakukan akses internet menggunakan telepon genggam tentu juga berpengaruh dalam hal pola pencarian dan penerimaan informasi yang mereka miliki. Salah satunya terkait dengan popularitas media sosial.

Indonesia telah dikenal sebagai negara yang sangat aktif menggunakan media sosial. Kota Jakarta dan Bandung di tahun 2012 memiliki pengguna Twitter yang paling aktif di dunia (Semiocast, 2012). Selain itu, jumlah pengguna Facebook, di Indonesia, juga tercatat sangat tinggi. Bahkan berbagai liputan media memberikan anekdot bahwa meskipun bagi beberapa masyarakat daerah terpencil di Indonesia akses listrik merupakan sebuah kemewahan, ternyata hal ini tidak menyurutkan minat mereka untuk membuat dan menggunakan Facebook (Ryssdal, 2014). Kepopuleran ini juga membuat ada anggapan dari masyarakat banyak bahwa Facebook adalah Internet karena akses mereka kepada Internet hanya terpaku pada penggunaan Facebook semata (Mirani, 2015; Pratiwi, 2015).

Apakah tingginya penggunaan media sosial ini berdampak baik terhadap perkembangan 
aktivisme? Tentunya hal ini membutuhkan penelitian lebih lanjut, namun, jika melihat apa yang terjadi selama periode satu dekade ke belakang, riset-riset dari Merlyna Lim memperlihatkan bahwa kesuksesan aktivisme yang diperantarai oleh media sosial ternyata masih sangat terbatas (Lim, 2013). Media sosial juga justru berpotensi menimbulkan simpul-simpul yang mempertebal fanatisme pada ketokohan politik dan memperkuat polarisasi di masyarakat (Lim, 2017), dan juga dipercaya sebagai salah satu penyebab munculnya beragam berita palsu dan hoaks (Ipsos-CIGI, 2019). Selain itu, melihat berbagai peristiwa politik di Indonesia, dapat dikatakan bahwa meskipun di satu sisi media sosial dapat menjadi perantara dari munculnya gerakan politik yang kreatif dan berbasiskan relawan, namun di sisi lain media sosial juga memiliki peran signifikan dalam munculnya kampanye politik berbasiskan fitnah, disinformasi, dan hoaks (Kaur et al., 2018; Nadzir, Seftiani, \& Permana, 2019).

Kesenjangan akses tidak hanya terkait dengan infrastruktur. Kesenjangan dalam hal kemampuan pemanfaatan teknologi juga masih terjadi di Indonesia. Penggunaan berbagai teknologi digital akan dapat menghasilkan suatu hal yang substansial apabila diimbangi dengan kesadaran masyarakat bahwa teknologi digital tidak hanya dapat digunakan dalam urusan hiburan dan perekonomian semata, namun juga dapat berguna sebagai alat yang dapat meningkatkan peran mereka sebagai warga negara. Kesadaran ini tentu akan sulit terwujud dalam kondisi masyarakat yang masih terkendala akses pendidikan yang tidak merata, karena secara rata-rata tingkat literasi masyarakat di Indonesia masih tergolong rendah (Aprionis, 2019). Semakin masyarakat memiliki tingkat literasi yang tinggi maka idealnya mereka akan semakin menyadari bahwa media digital dapat digunakan untuk berbagai hal lain yang lebih substansial berpengaruh pada kehidupan mereka.

Konsep ini juga secara spesifik berkaitan dengan tingkat literasi digital. Sayangnya, di Indonesia masih belum ada pemetaan sistematis tentang tingkat literasi digital dan di sisi lain, upaya untuk meningkatkan hal ini di Indonesia masih dinilai sporadis, tidak terkoordinasi dengan baik, dan tidak didukung maupun menghasilkan data yang dapat ditelaah lebih lanjut (Kurnia \& Astuti, 2017).

Selain bentuk pengukuran statistik yang umum dipublikasikan seperti jumlah pengguna internet dan pengguna media sosial, dibutuhkan pula data terkait penggunaan media digital yang dapat langsung berdampak pada gerakan masyarakat sipil di Indonesia. Laporan terkait adopsi teknologi digital pada beragam organisasi masyarakat sipil di berbagai daerah di Indonesia 
seperti yang telah dilakukan oleh Nugroho (Nugroho, 2011) perlu untuk dibuat kembali dalam kondisi terkini. Pemetaan ini menjadi krusial untuk memperlihatkan sejauh mana teknologi digital memang nyata memfasilitasi beragam gerakan sosial dan aktivisme, dan sekaligus memperlihatkan seperti apa peta permasalahan terkait aksesibilitas teknologi secara riil (Nugroho, 2011; Nugroho \& Syarief, 2012). Gambaran ini juga diperlukan untuk mengingatkan bahwa aktivisme digital adalah praktik yang dapat dilakukan seluruh masyarakat sipil dalam upaya untuk memperkuat demokrasi, dan bukan hanya milik masyarakat yang berada pada kota-kota besar yang ada di pulau Jawa.

Selanjutnya, konsep kedua yang akan diulas adalah terkait faktor visibilitas dan popularitas dalam aktivisme digital. Saat ini, berbagai praktik aktivisme digital memiliki berbagai tantangan agar tetap dapat menjadi gerakan yang berkelanjutan. Selain tantangan terkait aksesibilitas infrastruktur, dalam konteks ini, logika, taktik, dan strategi terkait visibilitas menjadi salah satu hal krusial dalam praktik aktivisme. Bentuk aktivisme paling nyata terlihat dari produksi, distribusi, sirkulasi, maupun amplifikasi konten dalam berbagai platform digital seperti media sosial, yang dilakukan para aktivis yang terlibat dalam suatu gerakan. Seperti halnya praktik komunikasi digital yang dilakukan secara komersial, strategi komunikasi untuk aktivisme digital juga harus memastikan faktor "tingkat keterlihatan" yang dapat menghasilkan tingkat keterlibatan yang tinggi. Visibilitas adalah tingkat keterlihatan, tingkat kejelasan, dan bagaimana sebuah aktivisme bisa memiliki nilai tambah, keunikan, dan hal-hal lain yang membuatnya "menonjol dari yang lain” (Hutchinson, 2019).

Visibilitas berkaitan dengan popularitas. Pada platform digital seperti media sosial, kepopuleran konten sebagian besar "dihitung", diukur dan dievaluasi dengan berbagai metrics yang tersedia. Metrics yang ada ini pun sebagian besar berdasarkan orientasi pada nilai komersial. Konten yang populer akan berguna bagi keberlangsungan penghasilan utama media sosial, yaitu terkait dengan pendapatan iklan. Oleh karena itu, para pelaku aktivisme digital sejak awal harus memiliki kesadaran bahwa teknologi yang mereka gunakan dalam praktik aktivisme memang tidak didesain untuk kepentingan publik. Lewat penggunaan sistem rekomendasi dan mekanisme algoritme, konten di media sosial yang populer memiliki tingkat keterlihatan atau visibilitas lebih tinggi dibandingkan dengan berbagai permasalahan publik. Selain itu, bagaimana algoritme melakukan "penilaian" terhadap sirkulasi konten yang ada di media sosial juga dianggap bermasalah karena pada akhirnya konten dan informasi yang terkait dengan gerakan 
sosial, memiliki nilai-nilai perubahan sosial, dan dalam hal ini dapat dikatakan memiliki 'dampak' baik, bisa saja dinilai sama ataupun lebih rendah dibandingkan konten hiburan yang bombastis dan sensasional, ataupun pesan-pesan misinformasi dan disinformasi. Hal ini juga terjadi karena belum ada mekanisme moderasi konten yang 100\% efektif untuk menilai "potensi" dampak baik dan buruk dari sebuah konten (Lee, 2018). Mekanisme rekomendasi ini didesain untuk membantu pengguna media sosial menemukan dan mengakses konten yang berpotensi mereka sukai. Dari waktu ke waktu, bagaimana mekanisme ini bekerja seringkali tidak sepenuhnya transparan, dan strategi digital yang telah dirancang oleh seorang aktivis untuk memaksimalkan praktik aktivisme digital mereka harus terus menerus menyesuaikan perubahan algoritme yang terjadi dari waktu ke waktu. Selain itu, media sosial dalam konteks aktivisme digital kerap dicitrakan sebagai wadah yang demokratis. Misalnya saja, platform ini menjanjikan bahwa semua suara dari masing-masing pengguna media sosial dikatakan memiliki "nilai" yang sama. Meskipun demikian, pada praktiknya seperti telah dipaparkan dalam penjelasan sebelumnya, algoritme tidak melakukan penilaian tiap pengguna media sosial dengan sama.

Dengan prinsip visibilitas ini, mesin di balik media sosial akan bekerja untuk mencari pengguna yang mampu menarik "perhatian" lebih banyak daripada yang lain. Perhatian juga akan berpotensi melahirkan berbagai bentuk keterlibatan (engagement), dan pada akhirnya menghasilkan konten yang bersifat viral. Oleh karena itu akan selalu ada pengguna yang memiliki nilai sebagai "power user" atau "influencer" dan dianggap mampu membuat jagat digital menjadi "ramai". Mekanisme algoritme dengan demikian akan lebih mementingkan konten-konten yang dihasilkan oleh para pengguna ini. Logika inilah yang secara inheren memperlihatkan adanya hierarki pengguna, dan dianggap tidak sesuai akan janji mengenai ruang yang lebih demokratis di media sosial (Dijck \& Poel, 2013).

Aktivisme digital yang berhasil menarik perhatian pada khalayak yang tepat akan berujung pada keberhasilan gerakan itu dalam mengumpulkan dan mengamplifikasi "perhatian" pada isu-isu sosial tertentu. Meskipun demikian dalam konteks ini, menjadi populer dan memiliki khalayak yang besar harus dilanjutkan dengan pengelolaan khalayak sebagai salah satu sumber daya yang penting. Praktik pembuatan basis data khalayak, pembuatan program komunikasi, edukasi, dan interaksi yang lebih rutin dan personal, pengelolaan komunitas dan jaringan untuk terlibat lebih lanjut dalam gerakan, hingga kemampuan untuk mengelola keterlibatan 
khalayak yang berkelanjutan adalah sisi lain dari praktik aktivisme digital yang juga harus diperhatikan secara seksama (Karpf, 2018).

Visibilitas gerakan dan konten yang dapat membawa popularitas semestinya tidak menjadi tujuan utama dari sebuah strategi aktivisme digital, karena strategi yang dilakukan dengan melulu mengikuti logika algoritme media sosial berpotensi menjadikan praktik aktivisme menjadi tidak otentik, dan bahkan berpotensi menimbulkan reaksi negatif dari publik secara umum, maupun dari para pendukung gerakan tersebut. Akan tetapi, mengacuhkan faktor visibilitas dan popularitas dalam aktivisme pun bukanlah sebuah keputusan yang bijak, karena "Popularitas konten dapat menunjukkan tidak hanya peningkatan visibilitas, tetapi juga bagaimana konten ini terhubung ke "kekuasaan" - faktor penting bagi kelompok dan individu yang aktif secara sosial dan terlibat dalam urusan [masyarakat] sipil, [dan isu-isu] publik saat ini” (Hutchinson, 2019, hal. 5). Selain itu, terkait dengan visibilitas dan popularitas, para pelaku aktivisme digital juga harus mulai menerjemahkan konsep dan relevansi "metrics" dan "key performance indicators" dari konteks komunikasi dan interaksi digital yang sebagian besar mengacu pada praktik komunikasi dan interaksi digital yang lebih bersifat komersial. Dalam hal ini, penting untuk memahami bagaimana mengevaluasi "keberhasilan" dari sebuah praktik aktivisme digital selain dari konteks teknologi namun juga dari berbagi dampak riil nya kepada masyarakat yang terkait dengan gerakan tersebut.

Pembahasan bagian terakhir akan memberikan paparan terkait konsep ekosistem dalam aktivisme. Rodríguez, Ferron, \& Shamas (2014) memberikan pengamatan mereka bahwa riset terkait aktivisme yang terlalu berfokus pada "kecanggihan" dan peran teknologi beresiko mengabaikan berbagai faktor sosial-politik dan historis, yang terkait dengan manusia sebagai agency atau piha yang aktif dalam praktik aktivisme. Riset tentang aktivisme dalam perspektif komunikasi untuk perubahan sosial perlu membahas hal mendasar terkait konteks historis, kompleksitas proses komunikasi, analisis ekonomi politik terkait teknologi digital, dan akhirnya, selalu mencoba memposisikan kebaruan atau keberlanjutan posisi riset dalam kaitannya dengan berbagai literatur yang ada dalam bidang komunikasi dan perubahan sosial (Rodríguez et al., 2014). Selain itu, berbagai paparan yang telah dieksplorasi sebelumnya tidaklah mengatakan bahwa tujuan dan strategi yang harus disusun dalam sebuah aktivisme digital harus melulu berkaitan dengan visibilitas, popularitas, dan viralitas. Praktik aktivisme digital tidak hanya terkait dengan teknologi sebagai sebuah "alat" dan "perangkat" dalam aktivisme, namun praktik 
ini akan selalu bersentuhan dengan ekosistem dimana praktik tersebut terjadi.

Tidak mungkin ada bentuk aktivisme digital yang dapat meraih, dan akan diterima semua pihak. Akan tetapi, tentu patut menjadi perhatian bahwa kegiatan aktivisme harus dirancang sedemikian rupa secara strategis untuk sedari awal dimunculkan, tumbuh dan berkembang dalam sebuah ekosistem yang tepat, sehingga gerakan dan pesan yang dilakukan dapat menjangkau pihak-pihak yang relevan dalam sebuah isu tertentu, tidak hanya pada khalayaknya, namun juga pada pihakpihak yang berperan sebagai intermediaries (perantara) dalam sebuah jaringan. Dalam tiap-tiap tahapan ini, tujuan dan sasaran yang spesifik dan dapat diukur secara konkret seperti halnya sebuah kampanye atau komunikasi pemasaran komersial juga perlu untuk disusun dengan tepat. Hutchinson (Hutchinson, 2019), misalnya, menekankan konsep microplatformization yang menekankan bahwa peran dan kemampuan social influencers, pihak agensi digital, dan pihak media arus utama menjadi krusial, agar pesan terkait aktivisme dapat menyebar secara lintas spektrum media (Hutchinson, 2019).

Konsep micro-platformization dapat menjadi pertimbangan dari praktik aktivisme. Dalam artian, riset-riset sebelumnya terkait peran teknologi digital dalam membantu organisasi masyarakatsipilmelakukan aktivisme lebih melihat praktik aktivisme dilakukan secara mandiri, ataupun hanya menyentuh kalangan sesama organisasi itu sendiri (Lim \& Nugroho, 2011; Nugroho, 2011). Masih jarang ditemukan kajian terkait praktik aktivisme yang kemudian mengaitkan bagaimana masyarakat sipil secara strategis dapat memperluas jangkauan aktivisme dengan menggunakan jaringan maupun melakukan kerjasama dengan organisasi yang mungkin tidak secara langsung berkaitan dengan organisasi masyarakat sipil atau lembaga swadaya masyarakat. Perlu misalnya, membuka kemungkinan bagi aktivis untuk melakukan kolaborasi secara strategis dengan pihak konsultan komunikasi ataupun dengan organisasi lain yang mungkin lebih bergerak pada tujuan komersial. Selain itu, tidak ada salahnya bagi para pelaku aktivisme digital untuk lebih mempelajari bagaimana mekanisme komunikasi pemasaran yang lebih komersial dilakukan, bukan untuk lalu ditiru secara mentah, namun untuk lebih mengadopsi hal-hal yang dapat membantu mencapai tujuan aktivisme mereka, misalnya dalam berbagai hal yang bersifat teknis seperti strategi pengumpulan dan pengelolaan data digital secara lebih efektif dan efisien, perancangan pesan komunikasi, pembuatan desain pesan, pengukuran dampak dari pesan komunikasi, dan lain sebagainya. Dalam sebuah organisasi 
masyarakat sipil, yang kerap memiliki kesulitan dalam bidang sumberdaya manusia, programprogram peningkatan kapasitas dalam hal komunikasi digital tentu menjadi hal yang mutlak diperlukan, agar orang-orang yang berada dalam organisasi tersebut dapat lebih paham tentang seluk beluk dari ekosistem digital yang bersifat riil (Rahmawan, 2018).

Selain itu, ekosistem aktivisme juga dapat dieksplorasi secara lebih mendetail dengan konsep "Roots, Routes, and Routers" atau “akar, rute, dan router" (Lim, 2018) untuk menggambarkan tiga mekanisme besar yang harus diperhatikan dalam analisis mengenai aktivisme digital. Yang pertama, "Roots" ialah penggalian akar permasalahan sosial ditelisik dari faktor historis dan kontekstual. Istilah "akar masalah ini” biasanya digunakan untuk menggambarkan hal terdalam yang menjadi pemicu sebuah kejadian berantai di masyarakat (Lim, 2018). Dalam kasus terjadinya berbagai gerakan sosial di masyarakat, akar penyebab ini juga adalah bagian fundamental yang dapat menjelaskan terjadinya perilaku kolektif yang bersifat khas. Para pengkaji aktivisme sepakat bahwa mengungkap akar masalah yang menjadi penyebab tindakan kolektif dan gerakan sosial adalah penting, meskipun dalam praktiknya, tetap saja akan sulit membangun hubungan sebab akibat antara gerakan dan akar penyebabnya. Hal yang kemudian secara logis dapat dilakukan adalah mengurai beberapa akar permasalahan yang tersembunyi dan saling kait mengait alih-alih memfokuskan analisis pada hal-hal yang populer atau tampak di permukaan. Selanjutnya, Lim juga menjelaskan tentang "Routes" atau kompleksitas komunikasi, media, dan ruang-ruang yang digunakan dalam sebuah gerakan sosial, bagaimana "ide" tentang gerakan muncul, mengkristal, berkembang, menyebar dan menjadi gerakan yang nyata (Lim, 2018). Dalam hal ini Lim menyatakan bahwa gerakan sosial sering menjadi terlihat ketika mereka terwujud dalam ruang publik dalam bentuk protes massa dan menjadi bagian dari liputan media seperti terekam dalam gambar 1 di bawah ini. Setelah gerakan kolektif ini muncul dan menampilkan "kekuatan" nya, baik jurnalis maupun akademisi cenderung

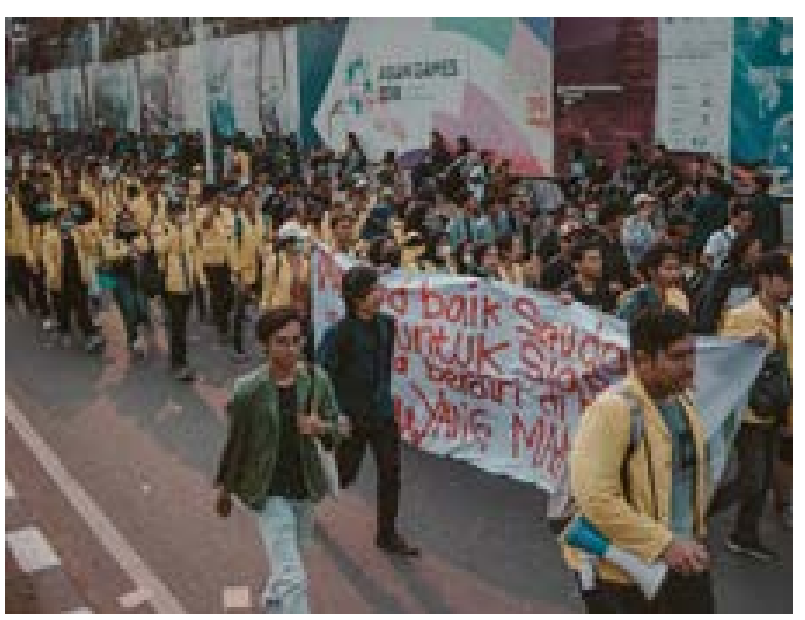

Sumber: https://twitter.com/piokharisma/ status/1177152382821552128/photo/3

Gambar 1 Aksi demonstrasi mahasiswa pada 2325 September 2019. Kegiatan ini ramai dengan tagar \#ReformasiDikorupsi 
berusaha untuk meneliti apa yang terjadi di permukaan untuk kemudian mencari penyebab atau pemicu gerakan tersebut. Hal ini, menurut Lim, kerap secara keliru menganggap bahwa suatu gerakan dimulai hanya ketika ia terlihat. Gerakan sosial jarang muncul hanya dalam satu kejadian dalam ruang yang bersifat tunggal. Sebuah gerakan sosial dapat muncul, tumbuh, dan mempertahankan dirinya, menyebar secara kolektif dalam berbagai ruang dan kejadian. Bahkan seringkali berbagai ide kolektif tentang gerakan muncul dalam ruangruang tertutup maupun tersembunyi, dan luput dari pengamatan publik. Hal inilah yang juga kemudian membuat sebuah gerakan sosial yang bersifat bottom-up dan memiliki skala besar dapat terdiri dari beragam gerakan kecil yang terjalin dalam sebuah irama pergerakan kolektif, dengan berbagai rute atau jalur gerakan yang saling berkelindan, dan seringkali tanpa adanya sebuah dirigen tunggal yang mengatur gerakan secara struktur dan sistematis.

Terakhir, Lim mengedepankan konsep tentang "Routers" sebagai konektivitas, aktor dan jaringan, bagaimana infrastruktur teknologi komunikasi seperti kombinasi antara yang digital dan analog, peran manusia dan mesin, serta interaksi dan peran media yang tradisional (konvensional) maupun kontemporer dalam sebuah pergerakan sosial (Lim, 2018). Dalam konteks teknologi, router menghubungkan dua atau lebih jalur data dari jaringan komputer yang berbeda. Dalam konteks gerakan sosial, analogi router digunakan untuk memperlihatkan terjadinya koneksi di antara berbagai jaringan sosial dan bagaimana berbagai pesan, narasi, dan simbol resistensi, diteruskan bersamaan dengan sentimen dan emosi yang melekat pada pesan-pesan tersebut. Dalam aksi langsung yang bersifat offline, kerumunan massa, aksi teatrikal, poster, dan artefak lainnya adalah "pesan" yang tidak hanya berguna pada saat aksi itu berlangsung namun juga dari bagaimana dokumentasi terkait hal-hal tersebut tersirkulasi secara luas dalam dunia digital.

Di sisi lain, bagaimana pesan politik dalam bentuk meme yang sebelumnya menjadi "bahasa" yang hanya ada di dunia digital, dapat kemudian berpindah menjadi artefak seperti poster dalam kegiatan luring atau offline. Selain itu, peran media tradisional dan media digital secara langsung juga akan berkaitan dengan bagaimana praktik aktivisme dapat dibingkai (misalnya menjadi positif atau negatif) dan menjadi pembahasan oleh publik yang lebih luas. Apa yang dianggap sebagai "kewajaran" dalam komunikasi online belum tentu akan dapat diterima dengan cara yang sama secara offline dan juga sebaliknya. Apa yang terjadi dalam lingkup offline bisa saja diceritakan dengan berbeda dalam dunia online. Kerumunan warga dapat memberikan interpretasi akan 
adanya "suara rakyat" dan "proses demokrasi", dan di sisi lain bisa menimbulkan interpretasi terkait "kerusuhan" dan "situasi tidak aman". Praktik aktivisme pada akhirnya akan berada dalam ruang publik yang terbuka dengan beragam interpretasi. Sehingga aktivisme pada akhirnya selalu harus dikelola dengan berbagai pertimbangan strategis dan mitigasi risiko yang jelas.

\section{SIMPULAN}

Popularitas aktivisme digital telah meningkat pesat dalam beberapa tahun terakhir. Berbagai gerakan sosial yang diperantarai teknologi digital dengan bentuk dan tujuan yang berbeda-beda telah muncul dan dibicarakan dalam ruang publik. Meskipun demikian, para akademisi pengkaji aktivisme digital terus mengingatkan bahwa analisis terkait aktivisme digital tidak dapat hanya menggunakan perspektif determinisme teknologi semata. Kritik terhadap popularitas aktivisme yang lebih tertuju pada "kecanggihan" teknologi digital juga sekaligus menolak persepsi bahwa keunggulan aktivisme digital hanya dapat terlihat pada "hasil" aktivisme seperti gerakan dan demonstrasi besar yang kemudian diliput secara luas oleh media arus utama. Dengan menggunakan metode penelusuran kajian pustaka dan mengulas beberapa literatur kunci terkait aktivisme digital, penelitian ini memaparkan konsep-konsep penting yang dapat digunakan sebagai landasan dalam melihat praktik aktivisme digital di Indonesia, yaitu terkait dengan aksesibilitas, visibilitas, popularitas dan ekosistem aktivisme.

Aksesibilitas melihat dari segi kompleksitas ketersediaan infrastruktur digital maupun dari kesiapan masyarakat dalam terpaan berbagai praktik aktivisme. Visibilitas dan popularitas mengulas bagaimana praktik aktivisme digital terutama akan selalu berkaitan dengan logika seperti algoritme dan metrics sebagai "mesin" di belakang media digital. Dalam konteks ini juga diperlukan penyesuaian antara bagaimana membuat aktivisme dapat "terlihat" (visible) dan "populer" pada khalayak yang tepat tanpa menghilangkan esensi dan substansi dari aktivisme tersebut. Terakhir, tentunya sangat penting untuk melihat aktivisme secara komprehensif dan holistis, dengan tidak hanya memperhatikan teknologi, namun juga faktor kondisi sosial dan budaya serta konteks historis dari aktivisme dan berbagai gerakan sosial yang muncul, berkembang dan menyebar di masyarakat.

Berbagai hal yang telah dipaparkan di atas tentu dapat menjadi bagian dari kajian akademis yang perlu dieksplorasi secara mendalam, tidak hanya oleh para pengkaji aktivisme, namun juga oleh para aktivis itu sendiri. Konsep aksesibilitas, visibilitas, popularitas dan ekosistem aktivisme 
dapat memberikan gambaran terkait peluang, hambatan, dan tantangan dalam rangka membangun gerakan sosial oleh masyarakat sipil dalam negara demokrasi seperti Indonesia.

\section{DAFTAR PUSTAKA}

Aprionis.(2019). Mendikbud akuitingkatliterasi Indonesia masih rendah - ANTARA News. Diambil 21 Juli 2019, dari Antaranews website: https://www.antaranews.com/ berita/793952/mendikbud-akui-tingkatliterasi-indonesia-masih-rendah

Ariyanti, S. (2013). Studi pengukuran digital divide di Indonesia. Buletin Pos dan Telekomunikasi, 11(4), 281. https://doi. org/10.17933/bpostel.2013.110402

Badan Pusat Statistik. (2018). Perkembangan indeks pembangunan teknologi informasi dan komunikasi (IP-TIK). Diambil dari Badan Pusat Statistik website: https://www. bps.go.id/pressrelease/2017/12/15/1310/ indeks-pembangunan-teknologi-informasidan-komunikasi--ip-tik--indonesia-tahun2016-sebesar-4-34-pada-skala-0---10-. html

Dijck, J. van, \& Poel, T. (2013). Understanding social media logic. Media and Communication, 1(1), 2-14. https://doi. org/10.4135/9781446270189

Freischlad, N. (2017). Indonesia's digital economy will thrive as small businesses come online, says gov't. Diambil 10 Oktober 2018, dari Tech In Asia website: https://www.techinasia.com/indonesiasdigital-economy-thrive-small-businessesonline-govt-plan

Friedland, L., Hove, T., \& Rojas, H. (2006). The networked public sphere. Javnost The Public, 13(4), 26. Diambil dari https:// www.tandfonline.com/doi/abs/10.1080/13 183222.2006.11008922

Gerbaudo, P. (2017). From cyber-autonomism to cyber-populism: an ideological analysis of the evolution of digital activism. tripleC: Communication, Capitalism \& Critique. Open Access Journal for a Global Sustainable Information Society, 15(2), 477-489. https://doi.org/10.31269/triplec. v15i2.773

Hadi, A. (2018). Bridging Indonesia's digital divide: rural-urban linkages? Jurnal Ilmu Sosial dan Ilmu Politik, 22(1), 17. https:// doi.org/10.22146/jsp.31835

Hutchinson, J. (2019). Micro-platformization for digital activism on social media. Information, Communication \& Society, O(0), 1-17. https://doi.org/10.1080/136911 8X.2019.1629612

Ipsos-CIGI. (2019). Cigi-ipsos global survey internet security \& trust 2019 part 3: social media, fake news \& algorithms. Paris: CIGI.

Joyce, M. (Ed.). (2010a). Digital activism decoded: the new mechanics of change. New York: International Debate Education Association.

Joyce, M. (2010b). Introduction: how to think about digital activism. In M. Joyce (Ed.), Digital Activism Decoded: The New Mechanics of Change (hal. 1-14). New York, NY: International Debate Education Association.

Karpf, D. (2016). Analytic activism: digital listening and the new political strategy. New York: Oxford University Press.

Karpf, D. (2018). Analytic activism and its limitations. Social Media and Society, 4(1). https://doi. org/10.1177/2056305117750718

Kaur, K., Nair, S. S., Kwok, Y., Kajimoto, M., 
Chua, Y. T., Labiste, M. D., ... Thanh, L. T. (2018). Information disorder in Asia. In M. Kajimoto \& S. Stanley (Ed.), Information Disorder in Asia: Overview of misinformation ecosystem in India, Indonesia, Japan, the Philippines, Singapore, South Korea, Taiwan, and Vietnam. Hong Kong: The University of Hong Kong.

Kurnia, N., \& Astuti, S. I. (2017). Peta gerakan literasi digital di Indonesia: studi tentang pelaku, ragam kegiatan, kelompok sasaran dan mitra. INFORMASI, 47(2), 149-166.

Lee, M. K. (2018). Understanding perception of algorithmic decisions: Fairness, trust, and emotion in response to algorithmic management. Big Data and Society, 5(1), 1-16. https://doi. org/10.1177/2053951718756684

Lim, M. (2003). From war-net to net-war: The internet and resistance identities in indonesia. International Information and Library Review, 35(2-4), 233-248. https:// doi.org/10.1080/10572317.2003.10762603

Lim, M. (2013). Many clicks but little sticks: social media activism in Indonesia. Journal of Contemporary Asia, 43(4), 636-657. https://doi.org/10.1080/00472336.2013.76 9386

Lim, M. (2017). Freedom to hate: social media, algorithmic enclaves, and the rise of tribal nationalism in Indonesia. Critical Asian Studies, 49(3), 411-427. https://doi.org/10 $.1080 / 14672715.2017 .1341188$

Lim, M. (2018). Roots, routes, routers: communications and media of contemporary social movements. Journalism \& Communication Monographs, 20(2), 92164.

Lim, M. (2019). Disciplining dissent: Freedom, control, and digital activism in Southeast
Asia. In R. Padawangi (Ed.), Routledge Handbook of Urbanization in Southeast Asia (hal. 478-494). London: Routledge.

Lim, M., \& Nugroho, Y. (2011, September). Introduction to the special issue on social implications of the icts in the Indonesian context. Internetworking Indonesia Journal, Vol. 3, hal. 1-3.

Mirani, L. (2015). Different worlds: millions of Facebook users have no idea they're using the internet. Diambil 12 Maret 2015, dari Quartz website: https:/qz.com/333313/ milliions-of-facebook-users-have-no-ideatheyre-using-the-internet/

Mirawati, I., \& Karimah, K. El. (2018). Chinese harmony communication theory: kompetensi komunikasi untuk keseimbangan hidup. Jurnal Manajemen Komunikasi, 3(1), 97-121.

Nadzir, I., Seftiani, S., \& Permana, Y. S. (2019). Hoax and misinformation in Indonesia: insights from a nationwide survey. Perspective, (92), 1-12. Diambil dari https://www.iseas.edu.sg/images/pdf/ ISEAS_Perspective_2019_92.pdf

Nishant, S., Puthiya, P. S., \& Sumandro, C. (Ed.). (2015). Digital activism in Asia reader. Diambil dari https://meson.press/ books/digital-activism-in-asia-reader/

Nugroho, Y. (2011). @ksi Warga: Kolaborasi, demokrasi partisipatoris dan kebebasan informasi - Memetakan aktivisme sipil kontemporer dan penggunaan media sosial di Indonesia. Manchester dan Jakarta: MIOIR dan HIVOS.

Nugroho, Y., Putri, D. A., \& Laksmi, S. (2012). Memetakan lansekap industri media kontemporer di Indonesia. Jakarta: Centre for Innovation Policy and Governance.

Nugroho, Y., Siregar, M. F., \& Laksmi, S. (2012). Memetakan kebijakan media di 
Indonesia. Jakarta: Centre for Innovation Policy and Governance.

Nugroho, Y., \& Syarief, S. S. (2012). Beyond click activism? New media and political processes in contemporary Indonesia. Diambil dari Friedrich-EbertStiftung website: https://www.research. manchester.ac.uk/portal/en/publications/ beyond-click-activism-new-media-andpolitical-processes-in-contemporaryindonesia(a0d000c9-2faf-4e80-9928bbf44330f35f).html

Postill, J., \& Saputro, K. (2017). Digital activism in contemporary Indonesia: victims, volunteers and voices. In E. Jurriëns \& R. Tapsell (Ed.), Digital Indonesia: Connectivity and Divergence (hal. 127145). Singapore: ISEAS Publishing.

Pratiwi, H. (2015). Many people, including Indonesians, still consider facebook as more popular than internet. Diambil 26 Mei 2016, dari Daily Social website: https://dailysocial.id/post/many-peopleincluding-indonesians-still-considerfacebook-as-more-popular-than-internet

Priyadharma, S. W. (2019). Model pemrosesan informasi Gregory Bateson dalam pendekatan sibernetis. Jurnal Manajemen Komunikasi, 4(1), 104-123. Diambil dari http://jurnal.unpad.ac.id/manajemenkomunikasi/article/view/21286

Rahmawan, D. (2018). Opportunities and challenges of digital media utilization for youth activism in Indonesia. In $\mathrm{S}$. W. Priyadharma, I. Mirawati, \& N. M. Hartoyo (Ed.), Indonesian Media and Social Transformation: Reports from the field (hal. 221-242). Bandung: BITREAD Publishing.

Rajan Anandan, Sipahimalani, R., Saini, S., Aryasomayajula, S., \& Smittinet, W. (2018).
e-Conomy SEA 2018 Southeast Asia's internet economy hits an inflection point. Diambil dari Think with Google APAC website: https://www.thinkwithgoogle. com/intl/en-apac/tools-resources/researchstudies/e-conomy-sea-2018-southeastasias-internet-economy-hits-inflectionpoint/

Rodríguez, C., Ferron, B., \& Shamas, K. (2014). Four challenges in the field of alternative, radical and citizens' media research. Media, Culture and Society, 36(2), 150-166. https:// doi.org/10.1177/0163443714523877

Ryssdal, K. (2014). No electricity in Indonesia, but there's Facebook. Diambil 1 Oktober 2018, dari Marketplace website: https:// www.marketplace.org/2014/07/02/tech/noelectricity-indonesia-theres-facebook

Semiocast. (2012). Twitter reaches half a billion accounts More than 140 millions in the U.S. Diambil 10 Juni 2017, dari Semiocast website: https://semiocast.com/ en/publications/2012_07_30_Twitter_ reaches_half_a_billion_accounts_140m in the_US

Seto, A. (2017). Netizenship, activism and online community transformation in Indonesia. Singapore: Palgrave Macmillan.

Suwana, F. (2019). What motivates digital activism? The case of the Save KPK movement in Indonesia. Information Communication and Society, 1-16. https:// doi.org/10.1080/1369118X.2018.1563205

Treré, E., Jeppesen, S., \& Mattoni, A. (2017). Comparing digital protest media imaginaries: anti-Austerity movements in Greece, Italy \& Spain. tripleC: Communication, Capitalism \& Critique. Open Access Journal for a Global Sustainable Information Society, 15, 404422. 
Wahyuni, H. I. (2013). Kebijakan "Media

Baru” Di Indonesia (Harapan, Dinamika, dan Capaian Kebijakan "Media Baru" di Indonesia). Yogyakarta: Gadjah Mada University Press. 